\title{
DZIALALNOŚĆ \\ TOWARZYSTWA OPIEKI NAD NIEULECZALNIE CHORYMI W WARSZAWIE (1897-1949). PRACA SIÓSTR FRANCISZKANEK OD CIERPIĄCYCH W WARSZAWSKIEJ KRÓLIKARNI
}

Naglącym i nierozwiązanym problemem szpitalnictwa warszawskiego końca XIX wieku była sprawa ludzi nieuleczalnie chorych, dotkniętych różnego rodzaju nowotworami, „rakowatych”, jak ich potocznie nazywano. Na terenie stolicy nie było żadnego specjalnego szpitala ani zakładu przeznaczonego dla tych osób. Chorzy ci byli wyrzucani z domów, wypisywani ze szpitali, izolowani przez otoczenie, a powodem tego był najczęściej lęk przed zarażeniem, bezradność wobec braku możliwości wyleczenia, a często odrażający wygląd. O sytuacji tych najbiedniejszych pisał doktor Juliusz Bandrowski w broszurze pt. „Najnieszczęśliwsi” wydanej w Warszawie w 1901 roku: „Bez szemrania zrezygnowali oni z miłosierdzia, bo - ni oczy ludzkie znieść już mogły widoku ran okropnych, ni powonienie wytrzymać ziejących od nich, gnilnych wyziewów, ni ręce je dotknąć. Nadawano im nazwę "dzikiego mięsa», na okropne je leczenie skazując. Więc miazgą wyżebranego nieświeżego mięsa okładali ci najnieszczęśliwsi swe rany, byle je wyleczyć!"”. Opinię doktora Bandrowskiego potwierdza notatka, znajdująca się $\mathrm{w}$ archiwum Zgromadzenia Sióstr Franciszkanek od Cierpiących w Warszawie, która w znamienny sposób opisuje los „rakowatych”: „Nauka, która olbrzymim krokiem dąży naprzód, gdzie każdy dzień znaczy się wielkimi odkryciami w dziedzinie medycyny - ta wiedza nie wynalazła dotąd pewnego środka na tę okropną zmorę ludzkości, jaką jest rak. Skazańcy ci, o ile są w do-

${ }^{1}$ J. B a n d row s k i, Najnieszczęśliwsi, Warszawa 1901, s. 10.

„Nasza Przeszłość” t. 131: 2019, s. 217-239. 
brych warunkach materialnych, dogorywają w swoich mieszkaniach, otoczeni opieką bliskich lub dobrze opłaconych pielęgniarzy, ale co mówić o tych biedakach, którzy nie mają gdzie głowy skłonić, będąc na łasce obcych lub zmęczonej długotrwałą chorobą rodziny, która chce się uwolnić od nich"2. Jedynym miejscem, gdzie mogli się schronić dotknięci nieuleczalnymi chorobami były przytułki noclegowe, ale i tutaj nie byli oni mile widziani ${ }^{3}$. Rada Główna Opiekuńcza, widząc tę potrzebę społeczną pragnęła otworzyć zakład dla nieuleczalnych, lecz w okresie jej działalności zdołano stworzyć dla nich jedynie osobny oddział w Szpitalu Dzieciątka Jezus i zarezerwowano kilka miejsc w przytułku w Górze Kalwarii ${ }^{4}$.

Zmianę położenia osób nieuleczanie chorych przyniosło powstanie Towarzystwa Opieki nad Nieuleczalnie Chorymi w Warszawie. Wśród jego inicjatorów, u początków jawi się osoba Zofii Michałowskiej, która odnajdywała chorych „rakowatych” przy pomocy sióstr ze Zgromadzenia Sióstr Miłosierdzia św. Wincentego a Paulo. Jednak jej dobroczynna działalność napotykała wiele trudności, ponieważ, jak już wcześniej wspomniano, w istniejących przytułkach noclegowych nie ich chciano przyjmować. Niektórzy z nich mieli również zakaz żebrania na ulicach - wszystko z powodu ran i zmienionego wyglądu. Pomocą w zorganizowaniu stacjonarnej opieki nad nieuleczalnymi stał się zapis, jaki uczyniła w swoim testamencie Aleksandra Augustowa hr. Potocka. Dzięki niemu możliwe było wynajęcie domu, przeznaczonego tylko dla chorych „rakowatych”, przy ulicy Wspólnej 69 w Warszawie oraz utrzymanie 4 łóżek na stałe. Dom dla nieuleczalnie chorych pod wezwaniem św. Józefa otwarto 15 lutego 1894 roku. Pierwszymi opiekunami i protektorami zostali: Zofia Michałowska, Zofia Górska, Natalja Wysiekierska, Janina hr. Potocka, Maria Morawska, Maria Wrotnowska, hr. Mycielska, Stanisław hr. Łubieński i Ludwik hr. Górski. Bardzo szybko przekonano się, jak ogromne jest zapotrzebowanie na tego typu placówkę. Już w roku następnym w zakładzie znalazło opiekę 13 chorych. Juliusz Bandrowski pisze, że „leczeniem chorych troskliwie zajął się dr Chrostowski, obejmując zarząd odświeżonego, czystego domku, skupiając około siebie coraz

\footnotetext{
${ }^{2}$ AFC, sygn. D I, T. I-Król/90, Prośba o wsparcie, s. 1.

${ }^{3}$ Zob. J. B a n d r o w s k i, Najnieszczęśliwsi, Warszawa 1901, s. 10-13.

4 Zob. Z. P odgórs k a-K l a w e, Szpitale warszawskie 1388-1945, Warszawa 1975, s. 199.
} 
więcej szlachetnych serc opiekunek. Młode panienki nawiedzały chore, pielęgnowały je, osładzając szarą ich dolę czytaniem książek"

Istniejącemu zakładowi należało nadać byt prawny, stąd zajęto się przygotowaniem ustawy, której tekst przesłano do Ministerstwa Spraw Wewnętrznych w Petersburgu. Ustawa Towarzystwa Opieki nad Nieuleczalnie Chorymi została zaaprobowana przez odnośne władze i zatwierdzona w dniu 14 lipca 1897 roku, a ogłoszona drukiem w 1898 roku. Celem Towarzystwa było udzielanie pomocy wyłącznie nieuleczalnie chorym z terenu Warszawy. Dla jego osiągnięcia, Towarzystwo w miarę swych funduszów mogło zakładać i utrzymywać przytułki dla tychże chorych i ambulatoria w stolicy i okolicach. Udzielało także bezpłatnej pomocy lekarskiej w domach chorych. Towarzystwo mogło również udzielać wsparcia materialnego w postaci odzieży, żywności, pewnych kwot pieniężnych, jak również mieszkania w przytułku tym, których stan zdrowia nie pozwalał zabezpieczyć sobie najkonieczniejszych potrzeb własną pracą ${ }^{6}$ W dniu 3 kwietnia 1898 roku zwołane zostało pierwsze zebranie członków i odbyły się wybory pierwszego Zarządu Towarzystwa Opieki nad Nieuleczalnie Chorymi. Do Rady Opiekuńczej weszły: Janina hr. Potocka, Gustawowa hr. Łubieńska, Maria Wrotnowska, Kazimiera Gruszczyńska, Janowa Lasocka oraz: Mieczysław ks. Woroniecki, Seweryn ks. Światopełk Czetwertyński, Adam hr. Zamoyski, Henryk Radziszewski oraz dr Witold Żurakowski. Naczelnym lekarzem Towarzystwa wybrano doktora Bronisława Chrostowskiego. Natomiast 26 kwietnia 1898 roku powołano Zarząd, którego kadencja miała trwać 3 lata. Prezesem został Adam hr. Zamoyski, zastępcą prezesa - Janina hr. Potocka, skarbnikiem - Henryk Radziszewski, sekretarzem dr Żurakowski. Jak wspomniano wyżej, jedną z członkiń Rady Opiekuńczej została Kazimiera Gruszczyńska, założycielka Zgromadzenia Sióstr Franciszkanek od Cierpiących, dlatego też od samego początku istnienia Zakładu dla Nieuleczalnie Chorych, opiekę nad chorymi sprawowały siostry franciszkanki od cierpiących ${ }^{7}$.

\footnotetext{
${ }^{5}$ J. B a n d r o w s k i, Najnieszczęśliwsi, s. 18.

${ }^{6}$ Zob. Ustawa Towarzystwa opieki nad nieuleczalnymi chorymi w mieście Warszawie, Warszawa 1898.

${ }^{7}$ Zob. J. B a n d r ow s k i, Najnieszczęśliwsi, s. 19-21; L. C z e r m i ń s k a, Wszystko zaczęto się w Kozienicach... Życie i dzieło Stugi Bożej Kazimiery Gruszczyńskiej, Kozienice 2017, s. 69-70.
} 
Zakład przy ulicy Wspólnej przeznaczony był tylko dla chorych kobiet. Dla pensjonariuszek, których liczba wzrosła już do 16, ułożono regulamin na wzór podobnych domów paryskich. Ponieważ był to jedyny tego typu zakład nie tylko w Warszawie, ale w całym Królestwie Polskim, liczba chorych, którym należałoby pomóc, szybko zaczęla przekraczać możliwości przytułku. W związku z tym rozpoczęto poszukiwania nowego miejsca w celu utworzenia większego szpitala dla nieuleczalnych. Zamysł udało się zrealizować w położonej na obrzeżach Warszawy Królikarni, posesji należącej kiedyś do Ksawerowej hr. Pusłowskiej. Istniał tam klasztor i kościółek wybudowany z przeznaczeniem dla księży emerytów. Jednak z powodu śmierci fundatorki nie był on nigdy wykorzystany zgodnie z pierwotnymi zamiarami. Spadkobierca majątku, Zygmunt hr. Pusłowski, mieszkał w Krakowie. Staraniem mecenasa Lucjana Wrotnowskiego nawiązano kontakt z hr. Pusłowskim, przedstawiając prośbę o ofiarowanie Królikarni na rzecz przytułku dla nieuleczalnie chorych. Hrabia wyraził zgodę, zastrzegając jedynie, by w podziemiach kościoła znajdowały się groby rodziny hrabiów Pusłowskich i książąt Druckich-Lubeckich. W przypadku likwidacji zakładu, posiadłość miała wrócić do właścicieli - spadkobierców ${ }^{8}$.

W czasie remontu Królikarni, budynek przystosowano dla potrzeb szpitala. Na parterze znajdowała się kuchenka z windą, pokój na bieliznę, sala opatrunkowa, mieszkanie dla kapelana, zakrystia oraz 4 pokoje dla chorych. Pierwsze piętro przeznaczono dla chorych nieuleczalnie dziewcząt, była tam również sala do pracy, jadalnia, pokój dozorczyń i osobny oddział dla chorych na raka. Przygotowano 40 miejsc: 2/3 miejsc przeznaczono dla ubogich i nieuleczalnie chorych kobiet, które nie miały możliwości przebywania w domu, w szpitalu lub innym zakładzie opiekuńczym, 1/3 miejsc przeznaczono dla chorych dzieci. 11 października 1898 roku, z pomocą pogotowia ratunkowego przeprowadzono chorych z domu przy ul. Wspólnej do nowego za$\mathrm{kładu}^{9}$ dla nieuleczalnie chorych, do Królikarni ${ }^{10}$. Jak opisywał T.T Świda w „Tygodniku Ilustrowanym”: „szły chore ze «żrącymi wrzo-

\footnotetext{
${ }^{8}$ Zob. AFC, sygn. D I, T. I-Król/19, Informacje dotyczące nieruchomości uregulowanej w księdze hipotecznej pod nazwą „Dobra Królikarnia B”, s. 38.

${ }^{9}$ W artykule, pisząc o Zakładzie dla Nieuleczalnie Chorych - Królikarnia, z uwagi na rolę, jaką spełniał będzie się zamiennie używać nazwy: zakład, przytułek, szpital.

${ }^{10}$ Zob. J. B a n d row s k i, Najnieszczęśliwsi, s. 21-27.
} 
dami», z «wilkiem» na twarzy, «rakiem» przynoszono dzieci ze strasznemi ranami, którym dłuższe albo krótsze życie miało być męką [...]. Wrót nie zawarto, nie wyrzucono ich precz, lecz oddano im na skraju cudnego parku maleńkie, a schludne zabudowania z kościółkiem, pierwotnie przeznaczonym dla księży emerytów [...]. Zaprawdę mało kto wie, zwłaszcza z Warszawian o nieuleczalnych w Królikarni [...] i nawet nie domyśla się, że poza tem pięknem i ta dziwną ciszą kryje się wielkie cierpienie" $"$.

Równocześnie z przytułkiem w Królikarni, Towarzystwo Opieki nad Nieuleczalnie Chorymi prowadziło też 3 lecznice (przy ul. Wspólnej 4, Piwnej 13 i na Sewerynowie 14) ${ }^{12}$, w których ubodzy chorzy otrzymywali bezpłatnie poradę, lekarstwa, często pomoc materialną i opiekę w domu. W 1900 roku udzielono w nich porad 42694 chorym (250 dziennie), w 1901 roku - 55059 chorym (310 dziennie) ${ }^{13}$. W roku 1903 statystyki przedstawiały się następująco: Lecznica I - porady w zakresie chorób wewnętrznych: 2435, chorób chirurgicznych: 3933, chorób dzieci: 2652, razem: 9020 porad (średnio dziennie 81 osób); Lecznica II - porady w zakresie chorób wewnętrznych: 3171 , chorób chirurgicznych: 3553, chorób dzieci: 3463, razem: 10187 porad (83 dziennie); Lecznica III - porady w zakresie chorób wewnętrznych: 2411, chorób chirurgicznych: 4301, chorób dzieci: 2241, razem: 8953 (dziennie 98 osób) ${ }^{14}$. „W domach odwiedza się 350 chorych. Tyle samo wykonuje się bezpłatnych szczepień. Lecznice utrzymują własne apteki, skąd wydaje się chorym po 30 i kilka tysięcy lekarstw, a nadto 500 pobiera się na recepty $\mathrm{z}$ aptek. Chorzy dostają również bony na kąpiele (1793 rocznie), na ciepłą strawę w garkuchniach Towarzystwa przeciwżebraczego (1336), odzież, bieliznę itp. Koszt utrzymania lecznic wynosi rocznie 7915 rubli, a koszt jednej porady lekarskiej wynosi 18 kopiejek tylko"

\footnotetext{
11 T.T Ś w i d a, Nieuleczalni w Królikarni. Garść wrażeń, „Tygodnik Ilustrowany” 1910; s. 32:651.

${ }^{12}$ Zob. J. B a n d r o w s k i, Najnieszczéśliwsi, s. 21.

${ }^{13}$ Zob. tamże, s. 21, także: AFC, sygn. D I, T. II-Król/26, Sprawozdanie z działalności Towarzystwa Opieki nad Nieuleczalnie Chorymi z roku 1901, s. 2.

${ }^{14}$ Zob. AFC, sygn. D I, T II-Król/29, Sprawozdanie z działalności Towarzystwa Opieki nad Nieuleczalnie chorymi z roku 1903, s. 2.

${ }^{15}$ J. B a n d row s k i, Najnieszczęśliwsi, s. 31.
} 
Ubogie, nieuleczalnie chore kobiety, kierowane były do zakładu przez różne instytucje: Wydział Opieki Społecznej, Ubezpieczalnię, Koło Pań, więzienia ${ }^{16}$. Jeszcze na samym początku działalności Towarzystwa ustalono, aby przed przyjęciem do zakładu jedna z członkiń Rady odwiedziła chorą, oceniła warunki, w jakich ona przebywa i po zasięgnięciu opinii lekarza, zadecydowała o przyjęciu do zakładu ${ }^{17}$. Procedurę tę wprowadzono w celu odszukania i udzielenia pomocy najbardziej potrzebującym, gdyż jak wynika z dokumentacji kilkakrotnie musiano odmówić chorym przyjęcia ze względu na brak miejsc ${ }^{18}$. Poniżej przedstawione zestawienia obrazują liczbę przyjmowanych chorych (z wyszczególnieniem rodzaju schorzenia) do roku 1919. W roku 1898 objęto opieką 21 chorych, w roku 1899 - 48 osób, w roku 1900 - 42 osoby, w roku 1901 - 46 osób, w roku 1902 53 osoby. Były to chore cierpiące z powodu chorób nowotworowych (w większości), wilka (toczeń rumieniowaty układowy), próchnienia kości, nieuleczalnych wrzodów, ciężkiego kalectwa. Stosunek dorosłych kobiet do dzieci wynosił w tych latach 2:1. W roku 1903 opiekę otrzymały 63 osoby (40 było przyjętych z domu, a 23 ze szpitali): przyjęto 29 osób, zmarło w ciągu roku 25 osób, 3 zostały wypisane, a stosunek dorosłych i dzieci wynosił 3:1. Najczęstsze przyczyny pobytu w zakładzie to choroby: rak, wilk, próchnienie kości, wrzody nieuleczalne, ciężkie kalectwo.

Jak można zauważyć, z każdym rokiem wzrastała liczba chorych objętych opieką. Właściwie do wybuchu I wojny światowej nie było większych trudności finansowych w zapewnieniu leczenia i opieki „rakowatym”. Zakład utrzymywał się ze składek od członków Towarzystwa Opieki nad Nieuleczalnie Chorymi, a były to osoby wywodzące się głównie z arystokracji i inteligencji warszawskiej, urządzano rauty, spotkania, zabawy, koncerty, odczyty, kwestowano ${ }^{19}$.

\footnotetext{
${ }^{16}$ Zob. AFC, sygn. D I, T. I-Król/6, Księga osób wizytujących w przytułku dla chorych nieuleczalnie w Królikarni (oraz sprawozdania z ruchu chorych - miesięczne i roczne zestawienia), s. 65.

${ }^{17}$ Zob. AFC, sygn. D I, T. I-Król/3, Protokół z X posiedzenia Rady Opiekuńczej Towarzystwa Opieki nad Nieuleczalnie Chorymi z dnia 18 października 1898 roku, s. 3.

${ }^{18}$ Zob. AFC, sygn. D I, T. I-Król/16, Korespondencja w sprawie chorych.

${ }^{19}$ Zob. AFC, sygn. D I, T. I-Król/3, Protokół z posiedzenia Rady Opiekuńczej Towarzystwa Opieki nad Nieuleczalnie Chorymi z dnia 1 czerwca 1910 roku, s. 1-2.
} 
Tab. 1 Zestawienie liczby pacjentów Zakładu dla Nieuleczalnie Chorych Królikarnia z roku $1915^{20}$

\begin{tabular}{|l|c|c|c|c|c|}
\hline \multirow{2}{*}{$\begin{array}{c}\text { Rodzaj } \\
\text { choroby }\end{array}$} & \multirow{2}{*}{$\begin{array}{c}\text { Z 1914 } \\
\text { roku }\end{array}$} & \multicolumn{3}{|c|}{ 1915 rok } & $\begin{array}{c}\text { Na rok } \\
\mathbf{1 9 1 6} \\
\text { pozostało }\end{array}$ \\
\cline { 3 - 6 } Rak & 13 & 54 & 6 & 40 & 21 \\
\hline Wilk & 4 & 1 & - & 1 & 4 \\
\hline $\begin{array}{l}\text { Próchnica } \\
\text { kości }\end{array}$ & 10 & 2 & - & - & 12 \\
\hline $\begin{array}{l}\text { Nieuleczalne } \\
\text { kalectwo }\end{array}$ & 7 & - & - & - & 7 \\
\hline $\begin{array}{l}\text { Owrzodzenia } \\
\text { chroniczne }\end{array}$ & 2 & - & - & 1 & 1 \\
\hline Inne & 1 & 1 & 2 & - & - \\
\hline Ogółem & $\mathbf{3 7}$ & $\mathbf{5 8}$ & $\mathbf{8}$ & $\mathbf{4 2}$ & $\mathbf{4 5}$ \\
\hline
\end{tabular}

Tab. 2 Zestawienie liczby pacjentów Zakładu dla Nieuleczalnie Chorych Królikarnia z roku $1917^{21}$

\begin{tabular}{|c|c|c|c|c|c|}
\hline \multirow{2}{*}{$\begin{array}{l}\text { Rodzaj } \\
\text { choroby }\end{array}$} & \multirow{2}{*}{$\begin{array}{c}\mathrm{Z} 1916 \\
\text { roku }\end{array}$} & \multicolumn{3}{|c|}{1917 rok } & \multirow{2}{*}{$\begin{array}{c}\text { Na rok } \\
1918 \\
\text { pozostało }\end{array}$} \\
\hline & & Przyjęto & Wypisano & Zmarło & \\
\hline Rak & 13 & 30 & 1 & 32 & 10 \\
\hline Wilk & 4 & 4 & - & 1 & 7 \\
\hline $\begin{array}{l}\text { Próchnica } \\
\text { kości }\end{array}$ & 15 & 8 & 2 & 7 & 14 \\
\hline $\begin{array}{l}\text { Nieuleczalne } \\
\text { kalectwo }\end{array}$ & 7 & - & - & 5 & 2 \\
\hline $\begin{array}{l}\text { Owrzodzenia } \\
\text { chroniczne }\end{array}$ & - & 1 & 1 & - & - \\
\hline Inne & 3 & 1 & 3 & - & 1 \\
\hline Ogółem & 42 & 44 & 7 & 45 & 34 \\
\hline
\end{tabular}

${ }^{20}$ Zob. AFC, sygn. D I, T. II-Król/30, Sprawozdanie z działalności Towarzystwa Opieki nad Nieuleczalnie Chorymi za rok 1915, s. 2.

${ }^{21}$ Zob. AFC, sygn. D I, T. II-Król/31, Sprawozdanie z działalności Towarzystwa Opieki nad Nieuleczalnie Chorymi za rok 1917, s. 2. 
Tab. 3 Zestawienie liczby pacjentów Zakładu dla Nieuleczalnie Chorych Królikarnia z roku $1918^{22}$

\begin{tabular}{|l|c|c|c|c|c|}
\hline \multirow{2}{*}{$\begin{array}{c}\text { Rodzaj } \\
\text { choroby }\end{array}$} & \multirow{2}{*}{$\begin{array}{c}\text { Z 1917 } \\
\text { roku }\end{array}$} & \multicolumn{3}{|c|}{ 1918 rok } & Na rok \\
\cline { 3 - 5 } & Przyjęto & Wypisano & Zmarło & $\begin{array}{c}\text { 1919 } \\
\text { pozostało }\end{array}$ \\
\hline Rak & 13 & 30 & 1 & 32 & 10 \\
\hline Wilk & 4 & 4 & - & 1 & 7 \\
\hline $\begin{array}{l}\text { Próchnica } \\
\text { kości }\end{array}$ & 15 & 8 & 2 & 7 & 14 \\
\hline $\begin{array}{l}\text { Nieuleczalne } \\
\text { kalectwo }\end{array}$ & 7 & - & - & 5 & 2 \\
\hline $\begin{array}{l}\text { Owrzodzenia } \\
\text { chroniczne }\end{array}$ & - & 1 & 1 & - & - \\
\hline Inne & 3 & 1 & 3 & - & 1 \\
\hline Ogółem & $\mathbf{4 2}$ & $\mathbf{4 4}$ & $\mathbf{7}$ & $\mathbf{4 5}$ & $\mathbf{3 4}$ \\
\hline
\end{tabular}

Po wybuchu I wojny światowej zaczęto odczuwać braki finansowe. Przyczyny tej sytuacji były różne: m.in. wyjazd wielu dobroczyńców z Warszawy z powodu działań wojennych, a także zmiana waluty. $\mathrm{Z}$ tego powodu szukano sposobów, aby nie doszło do zamknięcia zakładu, gdyż „przytułek Królikarnia jest konieczny, chorzy rakowaci nie powinni przebywać w domach prywatnych i szpitalach"23. Na apel o pomoc odpowiedzieli m.in.: Magistrat Warszawy, Amerykański i Angielski Czerwony Krzyż, Prywatna Lecznica Omega znajdująca się przy Alejach Jerozolimskich, kardynał Aleksander Kakowski, Nuncjusz Apostolski w Warszawie - Achilles Ratti. Dzięki uzyskanemu wsparciu szpital został zaopatrzony w opał, ziemniaki, leki, mydło, żywność i ubrania. Złagodziło to częściowo potrzeby zakładu. Od tego momentu do końca swojej działalności Towarzystwo Opieki nad Nieuleczalnie Chorymi będzie borykać się z trudnościami finansowymi.

Wobec coraz bardziej rosnących problemów materialnych, Towarzystwo zrezygnowało z działalności lecznic - ambulatoriów, aby wszyst-

${ }^{22}$ Zob. AFC, sygn. D I, T. II-Król/32, Sprawozdanie z działalności Towarzystwa Opieki nad Nieuleczalnie Chorymi za rok 1918, s. 2.

${ }^{23}$ AFC, sygn. D I, T. II-Król/31, Sprawozdanie z działalności Towarzystwa Opieki nad Nieuleczalnie Chorymi za rok 1917, s. 1. 
kie fundusze przeznaczać na zakład w Królikarni. Nadal kierowano prośby o pomoc do różnych osób i stowarzyszeń, organizowano kwesty i inne wydarzenia towarzyskie. Uzyskane w ten sposób dochody nie wystarczały jednak na pokrycie wszystkich kosztów prowadzenia zakładu i w roku 1919 zdecydowano o likwidacji Królikarni. Na początku zawieszono jedynie przyjmowanie chorych ze szpitali i zastrzeżono, że przy poprawie warunków materialnych likwidacja szpitala dla nieuleczalnych zostanie odwołana. Mimo krytycznej sytuacji, zakład został uratowany dzięki osobistemu zaangażowaniu doktora Bronisława Chrostowskiego. Przedstawiając konieczność istnienia tego typu placówki, zwrócił się on do Wydziału Szpitalnictwa i Dobroczynności Publicznej oraz do Ministerstwa Zdrowia o zapomogi. Zostały przyznane niewielkie dotacje, które pozwoliły na odwołanie decyzji o likwidacji szpitala ${ }^{24}$. Aby wspomóc działalność zakładu, Rada Towarzystwa wydawała także drukiem odezwy i ulotki, które nawoływały do zapisywania się do Towarzystwa Opieki nad Nieuleczalnie Chorymi i opłacania składek. W archiwum Zgromadzenia Sióstr Franciszkanek od Cierpiących zachowały się tego typu ulotki i pisma, niestety, nie są one datowane. Jedna z ulotek, wydana prawdopodobnie pod koniec lat 20. XX wieku, brzmiała: „Wśród przytu1ków, do których chronią się najtragiczniejsze przejawy nędzy i niedoli ludzkiej, jednym z najwięcej zasługujących na uwagę i ofiarność społeczeństwa, jest przytułek w Królikarni dla kobiet dotkniętych straszliwą, nieuleczalną chorobą raka. Oto powoli dokonywa tam życia szereg istot wśród cierpień przechodzących, zdawałoby się ludzką miarę. Można spotkać się z twierdzeniem, że społeczeństwo nasze posiada inne obowiązki, pilniejsze potrzeby do zaspokojenia, jak opiekę nad skazanymi na śmierć nieszczęsnymi istotami. Słuszny to może pogląd z utylitarnego punktu widzenia, ale $\mathrm{z}$ humanitarnego jest więcej jak bezwzględny. Wszak te nieszczęsne istoty, zanim zostały wyrwane ze strasznej nędzy i złożone w przytułku na łożu najcięższej niemocy, były członkami naszego społeczeństwa, współobywatelkami naszego kraju. Nie zapominajmy o nich, nie odwracajmy się obojętnie, gdy każdy miesiąc, tydzień, dzień każdy ich życia, zdążającego do śmierci, znaczy się dla nich okrutnym cierpieniem. Pospieszcie

${ }^{24}$ Zob. AFC, sygn. D I, T. II-Król/34, Sprawozdanie z działalności Towarzystwa Opieki nad Nieuleczalnie Chorymi za rok 1919, s. 1. 
z ulgą, żeby złagodzić cierpienie i zapewnić im choćby minimum tego, do czego ma prawo każda jednostka ludzka, zwłaszcza skazana na dożywotnią mękę. Obowiązek ten spełnia od lat 30 Towarzystwo Opieki nad Nieuleczalnymi, starając się najusilniej ulżyć temu ogromowi niedoli",25.

Po odwołaniu likwidacji, zakład nadal służył pierwotnie obranemu celowi, niosąc ulgę w cierpieniu i dając opiekę najnieszczęśliwszym, których nigdy nie brakowało. Poniżej przedstawiono zestawienie liczby pacjentów Zakładu Królikarnia z roku 1920.

Tab. 4 Zestawienie liczby pacjentów Zakładu dla Nieuleczalnie Chorych Królikarnia z roku $1920^{26}$

\begin{tabular}{|l|c|c|c|c|c|}
\hline \multirow{2}{*}{$\begin{array}{c}\text { Rodzaj } \\
\text { choroby }\end{array}$} & \multirow{2}{*}{$\begin{array}{c}\text { Z 1919 } \\
\text { roku }\end{array}$} & \multicolumn{3}{|c|}{ 1920 rok } & Na rok \\
\cline { 3 - 5 } & Przyjęto & Wypisano & Zmarło & $\begin{array}{c}\text { 1921 } \\
\text { pozostało }\end{array}$ \\
\hline Rak & 12 & 24 & 4 & 24 & 8 \\
\hline Wilk & 7 & 4 & 1 & - & 10 \\
\hline $\begin{array}{l}\text { Próchnica } \\
\text { kości }\end{array}$ & 7 & 6 & 2 & 2 & 9 \\
\hline $\begin{array}{l}\text { Nieuleczalne } \\
\text { kalectwo }\end{array}$ & 3 & - & 1 & - & 2 \\
\hline $\begin{array}{l}\text { Owrzodzenia } \\
\text { chroniczne }\end{array}$ & 2 & - & - & - & 2 \\
\hline Inne & 2 & 5 & - & 1 & 6 \\
\hline Ogółem & $\mathbf{3 3}$ & $\mathbf{3 9}$ & $\mathbf{8}$ & $\mathbf{2 7}$ & $\mathbf{3 7}$ \\
\hline
\end{tabular}

Jak wspomniano wyżej, od samego początku w placówkach prowadzonych przez Towarzystwo Opieki dla Nieuleczalnie Chorych pracowały siostry franciszkanki od cierpiących. Należy podkreślić, że pieczę nad posługą sióstr wobec chorych, także nad zarządem wewnętrznym zakładu Królikarnia od samego początku sprawowała założycielka - Matka Kazimiera Gruszczyńska. Do pracy w Królikarni

\footnotetext{
${ }^{25}$ AFC, sygn. D I, T. II-Król/49, Odezwa Zarządu Towarzystwa Opieki nad Nieuleczalnie chorymi, s. 1.

${ }^{26}$ Zob. AFC, sygn. D I, T. II-Król/35, Sprawozdanie z działalności Towarzystwa Opieki nad Nieuleczalnie Chorymi za rok 1920, s. 2.
} 
Matka Kazimiera delegowała siostry: Franciszkę Zwolińską, Annę Grzesiak, Walerię Muszalską ${ }^{27}$. Natomiast pierwszą przełożoną zakładu została siostra Władysława Radziejewska. Odznaczała się ona wielkim oddaniem dla chorych.

W cytowanym wyżej artykule, opublikowanym w „Tygodniku Ilustrowanym”, czytamy: „W ślad za chorymi przybyła, dbała o całość Zakładu, obecna przełożona p. Władysława Radziejewska, która z ewangelicznym zaparciem wraz z innemi pielęgniarkami opatruje rany - i jest matką, zwłaszcza dla dzieci skazanych na powolną śmierć. Toteż kocha te biedne istoty ponad życie. A jak one ją kochają!... Obok niej kapelan miejscowy w osobie ks. Zygmunta Gajewicza, codziennie sprawuje dla chorych niekrwawą Ofiarę, bądź pokrzepia ducha Słowem lub Ciałem Boga Jedynego"28. Siostry pracujące w zakładzie zajmowały się również ,wychowaniem, a nawet kształceniem młodych dziewczynek, które pozostają całe życie kalekami, zajmują się również bardzo serdecznie Siostry, ucząc je czytania, pisania, rachunków, robótek ręcznych bardzo ładnych, śpiewu chóralnego itp."29. W sprawozdaniu z działalności Towarzystwa Opieki nad Nieuleczalnie Chorymi z 1921 roku czytamy również, że zdrowsze lub podleczone dzieci umieszczano w odpowiednich zakładach ${ }^{30}$.

Informacje na temat pracy sióstr przy chorych można znaleźć w wielu dokumentach w archiwum Zgromadzenia Sióstr Franciszkanek od Cierpiących, m.in. w życiorysach Matki Kazimiery Gruszczyńskiej, w księgach wizyt kanonicznych, które były przeprowadzane w zakładzie oraz $w$ sprawozdaniach $\mathrm{z}$ działalności Towarzystwa Opieki nad Nieuleczalnie Chorymi. Z dokumentów wyłania się obraz ciężkiej pracy, wykonywanej przez siostry z radością i poświęceniem. Za swoją posługę otrzymywały wyłącznie wdzięczność pacjentów i społeczeństwa ${ }^{31}$. Wiktoria Bursiak w Życiorysie śp. Czcigodnej Mat-

\footnotetext{
${ }^{27}$ Zob. AFC, sygn. C I, T. II-MK/92, W. B u r s i a k, Życiorys śp. Czcigodnej Matki Kazimiery Gruszczyńskiej Założycielki ukrytego Zgromadzenia Sióstr Franciszkanek od Cierpiących w Warszawie, t. II, s. 63 (przyp. 1).

${ }^{28}$ T.T Ś w i d a, Nieuleczalni w Królikarni, s. 651.

${ }^{29}$ Zob. AFC, sygn. D I, T. I-Król/36, Sprawozdanie z działalności Towarzystwa Opieki nad Nieuleczalnie Chorymi z 1921 r.

${ }^{30}$ Tamże.

${ }^{31}$ Zob. AFC, sygn. B VI, T. I-Wiz/1, Księga wizyt kanonicznych od 1917-1945 przeprowadzonych przez Matkę Generalną Kazimierę Gruszczyńską, Magdalenę Łazowską oraz przez Delegatki Matek, s. 61.
} 
ki Kazimiery Gruszczyńskiej... pisze: „Królikarnia to ostoja strasznej nędzy, cierpienia fizycznego i moralnego, ludzi wykluczonych ze społeczeństwa, [...] to szkoła cierpienia, kuźnia świętych, polski Madagaskar" 32 . Pracę sióstr pielęgniarek bardzo dobrze przedstawia także notatka, która zachowała się w archiwum zgromadzenia: „Dość jako przykład postawić pracę członkiń Towarzystwa [tutaj: Towarzystwa Pielęgnowania Chorych Świętego Józefa ${ }^{33}$ w Zakładzie Królikarnia dla nieuleczalnych (rakowatych) kobiet. Kto raz zwiedził ten polski Madagaskar, ten może sobie wyobrazić ile trzeba ofiarnej miłości i bezgranicznego poświęcenia, by nieść ulgę tylu cierpiącym, bez okazania wstrętu wzdrygającej się ludzkiej natury wobec grozy wyglądu osób dotkniętych tą chorobą, a jednak siostry ubiegają się o posługę przy tych nieszczéśliwych [...] i otaczają czułą opieką tych prawdziwie trędowatych" ${ }^{34}$. Bardzo ważnym momentem nie tylko dla sióstr, ale także dla chorych było uzyskanie pozwolenia na odprawianie mszy św. i nabożeństw w kaplicy przytułku. O tym fakcie Matka Kazimiera Gruszczyńska pisała: „Bogu dzięki, że chorzy ci, prawdziwi Łazarze, są zadowoleni, mają opiekę tak dla ciała jak i duszy" 35 . Siostry wspierały również moralnie i duchowo chorych załamanych, umierających, którym towarzyszyły do końca życia. O wadze tej posługi sióstr franciszkanek wśród chorych kobiet świadczy opinia zawarta w Sprawozdaniu z działalności Towarzystwa Opieki nad Nieuleczalnymi z 1921 roku, która brzmi: „Należy jeszcze podnieść i rolę moralną, a zarazem psychiczną Przytułku Królikarnia. Spełnia on możliwie dobrze swoje zadanie dając opiekę najnieszczęśliwszym chorym kobietom, co głównie trzeba zawdzięczać siostrom i ks. Kanonikowi"36. Siostry dbały także o wypełnienie czasu wolnego chorych. W zakładzie zorganizowana była biblioteka książek i czasopism oraz radio ${ }^{37}$.

\footnotetext{
${ }^{32}$ AFC, sygn. C I, T. II-MK/92, W. B u r s i a k, Życiorys śp. Czcigodnej Matki, s. 68. ${ }^{33} \mathrm{Tj}$. Towarzystwa Pielęgnowania Chorych św. Józefa - tożsamego ze Zgromadzeniem Sióstr Franciszkanek od Cierpiących. Więcej na ten temat: L. C z e r m i ń s k a, Wszystko zaczęto, s. 58-59.

${ }^{34}$ AFC, sygn. C I, T. II-MK/91, Życiorys śp. Kazimiery Gruszczyńskiej, Założycielki i długoletniej Prezeski „Towarzystwa Pielęgnowania Chorych Świętego Józefa Przytulisko" w Warszawie, s. 49.

35 AFC, sygn. B VI, T. I-Wiz/1, Księga wizyt kanonicznych, s. 39.

${ }^{36}$ AFC, sygn. D I, T. II-Król/36, Sprawozdanie z działalności Towarzystwa Opieki nad Nieuleczalnie Chorymi z 1921 roku.

${ }^{37}$ Zob. AFC, sygn. D I, T. I-Król/37, Informacja historyczna o Domu Zgromadzenia Sióstr Franciszkanek od Cierpiących - Królikarnia, s. 3; także: AFC, sygn. D I, T. II-
} 
O tym jak wyglądała praca sióstr dowiadujemy się także z pisma Prezesa Towarzystwa Opieki nad Nieuleczalnie Chorymi wysłanego do Wydziału Opieki Społecznej i Zdrowia Publicznego Zarządu Miejskiego w Warszawie z dnia 26 września 1934 roku w sprawie rewizji decyzji o obniżeniu dotychczasowej stawki dziennej na utrzymanie i leczenie chorych z 2.75 złotych do 2.40 złotych: „Chore dostarczane do przytuliska są prawie zawsze przykute do łóżka, znajdują się w stanie najcięższym, beznadziejnym wymagającym uciążliwej obsługi, ręcznego karmienia, kilkakrotnego w dzień opatrunku (rany), zmiany częstej bielizny, a przede wszystkim stałych i częstych zastrzyków morfiny, która, będąc jednem z najdroższych lekarstw nieraz podwaja koszty utrzymania. Tak wiec, gdy się weźmie pod uwagę, że pensjonariuszka Królikarni za wyasygnowaną zań opłatę otrzymuje: stały dozór i opiekę lekarską, wszelkie opatrunki i lekarstwa, a w tem morfinę, pielęgnowanie aż do odręcznego karmienia włącznie i kilkakrotne nieraz na dzień zabiegi i zastrzyki, ubranie i bieliznę, tak osobistą jak i pościelową, pranie ciągle zmienianej bielizny, higieniczne, nieraz indywidualne odżywianie, w razie śmierci, trumnę i pogrzeb, to trzeba przejść do przekonania, że tylko ofiarna, bezinteresowna praca personelu, składającego się z osób stanu zakonnego, umożliwia tak tanie utrzymanie chorych oraz że zarząd m. Warszawy oddając swoich chorych do Królikarni, robiłby na tem oszczędności, gdyby opłacał faktyczny koszt utrzymania ich przez nasz zakład (2.95 złotych). Przytułek w Królikarni jest zakładem dobroczynnym, który oprócz chorych przesyłanych przez Zarząd Miejski i Kasę Chorych, ma jeszcze innych chorych utrzymywanych często bezpłatnie"38. Także w wielu sprawozdaniach rocznych podkreślano rolę sióstr franciszkanek od cierpiących oraz fakt, że dzięki ich staraniom i pracy koszty utrzymania zakładu były niższe: „Rzuca się jednak przede wszystkim w oczy stosunkowo bardzo niewielka suma na wydatki personalne (zarządzająca, infirmerka, służba niższa/ zazwyczaj wydatki na administrację $\mathrm{w}$ podobnym rodzaju instytucjach w Warszawie stanowią

Król/47, Pismo Prezesa Towarzystwa Opieki nad Nieuleczalnie Chorymi do Ministerstwa Poczt i Telegrafów, Wydział Radiofoniczny z dnia 24 maja 1936 roku, s. 1-2.

${ }^{38}$ AFC, sygn. D I, T. II-Król/33, Pismo Prezesa Towarzystwa Opieki nad Nieuleczalnie Chorymi do Wydziału Opieki Społecznej i Zdrowia Publicznego Zarządu miejskiego w Warszawie z dnia 26 września 1934 roku w sprawie rewizji decyzji o obniżeniu dotychczasowej stawki dziennej na utrzymanie i leczenie chorych, s. 1-2. 
znaczną odsetkę ogólnych wydatków, kiedy w Królikarni przy personelu złożonym z 12 osób /5 przy chorych i 7 przy gospodarstwie) wynosi zaledwie $12 \%, " 39$.

Do obowiązków sióstr, oprócz pracy przy chorych, należało również: prowadzenie spraw administracyjnych, praca w kuchni, pralni, gospodarstwie, a także kwesta wśród okolicznych ogrodników. Wszystko to miało na celu wspomaganie funkcjonowania zakładu. „Tak mały koszt utrzymania przytułku w Królikarni przypisać należy gospodarstwu rolnemu i domowemu jakie prowadzi w przytułku Siostra Zarządzająca. Przytułek posiada własnego konia, dwie krowy, nierogaciznę i drób. Z gospodarstwa zaś 2 morgów ziemi ofiarowanej łaskawie dla przytułku przez sąsiada p. Antoszewskiego i 3 morgów ziemi wydzierżawionej od Zarządu Dóbr Wilanów, posiada własne kartofle, warzywa itp. Za pośrednictwem wydziału Dobroczynności Publicznej przytułek Królikarnia otrzymał niektóre produkty po cenach niższych od rynkowych (mąkę, ryż, kaszę, groch, fasolę, cukier i mięso z jatki na Solcu)" 40 .

Siostry franciszkanki od cierpiących były z nieuleczalnie chorymi przez wszystkie lata działalności zakładu. Były w tych lepszych czasach i w tych cięższych, były także w czasie okupacji. Już na początku II wojny światowej, w pierwszych dniach września 1939 roku szpital został zbombardowany przez lotnictwo niemieckie, a potem przez kilka dni był ostrzeliwany. Straty materialne były bardzo duże: częściowo zniszczone zostały ściany, sufity, dach, a także kaplica ${ }^{41}$. Po kapitulacji rządu polskiego, 22 września 1939 roku przystąpiono do zabezpieczenia budynków. Do pracy włączył się cały personel pod kierunkiem ówczesnej przełożonej siostry Klary Cyrankowskiej ${ }^{42}$.

Kiedy w 1941 roku władze okupacyjne zabroniły istnienia towarzystw polskich, rozwiązane zostało także Towarzystwo Opieki nad Nieuleczalnie Chorymi ${ }^{43}$. Mimo zakazu, Zarząd postanowił nadal

\footnotetext{
${ }^{39}$ AFC, sygn. D I, T. I-Król/38, Sprawozdanie z działalności Towarzystwa Opieki nad Nieuleczalnie Chorymi z 1926 roku.

${ }^{40}$ AFC, sygn. D I, T. I-Król/36, Sprawozdanie z działalności Towarzystwa Opieki nad Nieuleczalnie Chorymi z 1921 roku.

${ }^{41}$ Zob. AFC, D I, T. I-Król/90, Zebrane wiadomości historyczne o Królikarni, s. 7; także: H. J o d k o w s k i, Szpital w Królikarni, „Kronika Warszawy” 1975, nr 3/23, s. 43. ${ }^{42}$ Zob. tamże, s. 44.

${ }^{43}$ Zob. AFC, D I, T. I-Król/90, Zebrane wiadomości, s. 8.
} 
prowadzić pracę, a działalność Towarzystwa zawieszono jedynie formalnie. Zwiększyło to jednak trudności zdobywania funduszy, żywności i innych środków do utrzymania. Kierowniczka zakładu musiała starać się o zabezpieczenie bytu szpitala ${ }^{44}$.

Zakład funkcjonował dalej i niósł pomoc już nie tylko chorym nieuleczalnie. W 1940 roku do Królikarni zgłosił się dr Stefan Kwieciński, który pracował bez wynagrodzenia na rzecz chorych i dodatkowo rozwinął działalność szpitala. Zorganizował specjalny gabinet zabiegowy w jednej $\mathrm{z}$ sal, gdzie udzielał pomocy rannym żołnierzom i oficerom polskim, którzy uniknęli niewoli po kapitulacji Warszawy. W późniejszych latach operował i opatrywał rannych w akcjach bojowych. Dla ułatwienia wstępu na teren szpitala wywieszono napis, że odwiedzanie chorych odbywa się codziennie. Natomiast na budynku umieszczono tablicę w języku polskim i niemieckim o treści: „Zakład dla Nieuleczalnie Chorych".

Po wybuchu powstania zwiększyła się liczba podopiecznych. Na terenie przytułku schronienie znalazły matki z dziećmi, starcy, ranni cywile i żołnierze. Liczba osób szukających pomocy na terenie zakładu rosła bardzo szybko. Ludzi lokowano w samym szpitalu, kościele, szopach i piwnicach. Rozpoczęto wydawanie posiłków, początkowo dla dzieci i starców, później korzystali z nich już wszyscy. Na terenie Królikarni uruchomiono piekarnię, w której wypiekano chleb z odciśniętym znakiem kotwicy ${ }^{45}$. Tragicznym dla szpitala był dzień 16 września 1944 roku. Na zakład padły niemieckie bomby, pod gruzami zginęło 10 chorych, oraz 5 sióstr z personelu. Były to: Klara Cyrankowska - przełożona, Wincenta Borkowska - pielęgniarka, Krystyna Petrulewicz - salowa, Aleksandra Wawrowska - pielęgniarka, Antonina Cieśluk - salowa ${ }^{46}$. Ciała zabitych pochowano nocą na terenie $\operatorname{ogrodu}^{47}$. Natomiast 24 września 1944 ocalałe siostry franciszkanki oraz uchodźcy zostali wywiezieni do Pruszkowa, chorych zaś z kapelanem przewieziono do Szpitala Czerwonego Krzyża na Okęciu.

\footnotetext{
${ }^{44}$ Zob. H. J o d k o w s k i, Szpital w Królikarni, s. 44.

${ }^{45}$ Zob. tamże, s. 45.

${ }^{46}$ Zob. AFC, D I, T. I-Król/90, Zebrane wiadomości, s. 9.

${ }^{47} 09$ IX 1947 roku zwrócono się do z prośbą do Sądu Grodzkiego o pozwolenie na ekshumacje ciał sióstr. Znalezione szczątki pochowano we wspólnych grobach Zgromadzenia na Powązkach. Zob. AFC, sygn. D I, T. I-Król/11, Podanie do Sądu Grodzkiego z dn. 09 IX 1947 r.
} 
Kilku siostrom udało się wrócić z Pruszkowa do Warszawy, dzięki czemu szpital mógł funkcjonować ${ }^{48}$.

Zwrócić należy także uwagę na dużą liczbę chorych przyjmowanych do zakładu w okresie okupacji hitlerowskiej. W samym maju 1944 roku przyjęto 41 chorych, w tym okresie zmarła 1 osoba. Do czerwca 1944 roku przyjęto 101 osób $^{49}$. Jest to tym bardziej godne uwagi i podziwu ze względu na trudności związane z wojną i okupacją.

Tab. 5 Zestawienie liczby pacjentów Zakładu dla Nieuleczalnie Chorych Królikarnia od 1 kwietnia 1938 do 1 kwietnia $1939^{50}$

\begin{tabular}{|l|c|c|c|c|c|}
\hline \multirow{2}{*}{\begin{tabular}{c}
\multirow{2}{*}{$\begin{array}{c}\text { Rodzaj } \\
\text { choroby }\end{array}$} \\
Na 1 IV
\end{tabular}} & \multicolumn{3}{|c|}{ 1 IV 1938 - 1 IV 1939 } & \multirow{2}{*}{ Pozostalo } \\
\cline { 3 - 6 } & Przyjęto & Wypisano & Zmarło & \\
\hline Rak & 28 & 81 & 10 & 70 & 29 \\
\hline Wilk & 6 & 2 & 4 & - & 4 \\
\hline $\begin{array}{l}\text { Próchnica } \\
\text { kości }\end{array}$ & 2 & 1 & 1 & - & 2 \\
\hline $\begin{array}{l}\text { Nieuleczalne } \\
\text { kalectwo }\end{array}$ & - & - & - & - & - \\
\hline $\begin{array}{l}\text { Owrzodzenia } \\
\text { chroniczne }\end{array}$ & 1 & - & - & - & 1 \\
\hline Inne & 2 & 4 & - & 1 & 5 \\
\hline Ogółem & $\mathbf{3 9}$ & $\mathbf{8 8}$ & $\mathbf{1 5}$ & $\mathbf{7 1}$ & $\mathbf{4 1}$ \\
\hline
\end{tabular}

${ }^{48}$ Zob. AFC, sygn. D I, T. I-Król/22, Protokół z Ogólnego Zebrania Towarzystwa Opieki nad Nieuleczalnie Chorymi z dnia 24 października 1946 roku, s. 2.

${ }^{49}$ Zob. AFC, sygn. D I, T. I-Król/6, Księga osób, s. 96.

${ }^{50}$ Zob. AFC, sygn. D I, T. II-Król/55, Sprawozdanie z działalności Towarzystwa Opieki nad Nieuleczalnie Chorymi za rok 1939, s. 2. 
Tab. 6 Zestawienie liczby pacjentów Zakładu dla Nieuleczalnie Chorych Królikarnia za rok $1943^{51}$

\begin{tabular}{|l|c|c|c|c|c|}
\hline \multirow{2}{*}{$\begin{array}{c}\text { Rodzaj } \\
\text { choroby }\end{array}$} & \multirow{2}{*}{$\begin{array}{c}\mathbf{Z 1 9 4 2} \\
\text { roku }\end{array}$} & \multicolumn{3}{|c|}{ 1943 rok } & $\begin{array}{c}\text { Pozostało } \\
\text { na rok } \\
\mathbf{1 9 4 4}\end{array}$ \\
\cline { 3 - 6 } Rak & 22 & 63 & 4 & 57 & 24 \\
\hline Wilk & 6 & 1 & 1 & - & 6 \\
\hline $\begin{array}{l}\text { Próchnica to } \\
\text { kości }\end{array}$ & 1 & - & - & - & 1 \\
\hline $\begin{array}{l}\text { Nieuleczalne } \\
\text { kalectwo }\end{array}$ & - & - & - & - & - \\
\hline $\begin{array}{l}\text { Owrzodzenia } \\
\text { chroniczne }\end{array}$ & 1 & - & - & 1 & - \\
\hline Inne & 4 & 6 & 2 & 4 & 4 \\
\hline Ogółem & $\mathbf{3 4}$ & $\mathbf{7 0}$ & $\mathbf{7}$ & $\mathbf{6 2}$ & $\mathbf{3 5}$ \\
\hline
\end{tabular}

Po oswobodzeniu Warszawy, w styczniu 1945 przystąpiono do odbudowy zakładu. Chore, będące pod opieką sióstr, tymczasowo przekazano pod opiekę miejscowemu szpitalowi, a siostry franciszkanki czynnie zaangażowały się w prace remontowe. Były to: Salomea Raykowska, Eugenia Raabe, Anna Salmanowicz, Stefania Madej. Pomocą przy odbudowie szpitala służyli także bezdomni działacze z okresu wojny, a pracami remontowymi kierował Apolinary Zdziarski - majster budowlany ${ }^{52}$. Do października 1946 doprowadzono do użytku wszystkie pomieszczenia z ocalałej części budynku i przygotowano sale dla chorych ${ }^{53}$. Remont, jak również zakup łóżek oraz sprzętu medycznego, gospodarczego i pościeli był możliwy m.in. dzięki dotacjom z Ministerstwa Zdrowia i Opieki Społecznej ${ }^{54}$. Wznowiono także działalność formalnie zawieszonego Towarzystwa

51 Zob. AFC, sygn. D I, T. II-Król/59, Sprawozdanie z działalności Towarzystwa Opieki nad Nieuleczalnie Chorymi za rok 1943, s. 2.

${ }^{52}$ Zob. H. J o d k o w s k i, Szpital w Królikarni, s. 46; AFC, D I, T. I-Król/90, Zebrane wiadomości, s. 9.

${ }^{53}$ Zob. H. J o d k o w s k i, Szpital w Królikarni, s. 46.

${ }^{54}$ Zob. AFC, sygn. D I, T. I-Król/37, Informacja historyczna o Domu Zgromadzenia Sióstr Franciszkanek od Cierpiących - Królikarnia, s. 7. 
Opieki nad Nieuleczalnie Chorymi. 24 października 1946 roku zwołano walne zebranie, powołano nowy Zarząd i Radę Opiekuńczą. Prezesem został mecenas Henryk Hebel, a w skład Rady weszły siostry franciszkanki: s. Wiktoria Bursiak i s. Franciszka Stępniak ${ }^{55}$. Wystąpiono także do władz administracyjnych o rejestrację Towarzystwa Opieki nad Nieuleczalnie Chorymi, dołączając Statut oraz listę członków ${ }^{56}$.

Uroczystego otwarcia i poświecenia szpitala dokonano 24 września 1947 roku. Zdołano utworzyć 45 miejsc dla kobiet chorych na nowotwory. Tylko w roku 1948 zakład udzielił pomocy 101 nieuleczalnie chorym kobietom $^{57}$. Nie było jednak ciągle odpowiedzi z ministerstwa w sprawie rejestracji Towarzystwa. Odpowiedź, jaka nadeszła 26 października 1949 roku zawierała decyzję o likwidacji Towarzystwa Opieki nad Nieuleczalnie Chorymi jak również szpitala, wydaną przez Wydział Społeczno-Polityczny Ministerstwa Administracji Publicznej. Powyższą decyzję uzasadniano bezprzedmiotowością jego istnienia, ze względu na kasację wszystkich organizacji tego typu o charakterze lokalnym zamierzoną w przyszłości. 14 grudnia 1949 roku likwidator przejął książki czekowe, blankiety i pieczątki Towarzystwa ${ }^{58}$. W chwili likwidacji szpital liczył ok. 30 chorych. Zaproponowano przyjmowanie również mężczyzn, gdyż to uzupełniłoby stan chorych powyżej 40 osób i nie doszłoby do likwidacji placówki, która była jedyną o takim charakterze na terenie Warszawy. Dlatego też siostry poprosiły o pomoc doktora Franciszka Łukaszczyka, dyrektora Instytutu Rakowego. Dokonał on wizytacji zakładu i podjęto wtedy decyzję, że do szpitala będą przyjmowani także mężczyźni, a Instytut będzie mógł także kierować swoich chorych ${ }^{59}$.

Pomimo stałego rozwoju zakładu i ogromnej potrzeby na jego istnienie, Zakład dla Nieuleczalnie Chorych w Królikarni został przejęty wraz z całym inwentarzem przez Ministerstwo Zdrowia i upaństwowiony dnia 30 kwietnia 1950 roku. Mimo to placówka służyła nadal osobom nieuleczalnie chorym. Jednak w 1954 roku została przekształcona na

\footnotetext{
${ }^{55}$ Zob. AFC, D I, T. I-Król/90, Zebrane wiadomości, s. 11.

56 Zob. AFC, sygn. D I, T. II-Król/11, Pismo do Władz Administracyjnych miasta Warszawy o rejestrację Towarzystwa Opieki nad Nieuleczalnie Chorymi z dnia 24 października 1946 roku,

${ }^{57}$ Zob. H. J o d k o w s k i, Szpital w Królikarni, s. 46-47.

${ }^{58}$ Zob. AFC, D I, T. I-Król/90, Zebrane wiadomości, s. 11.

59 Zob. AFC, sygn. D I, T. I-Król/22, Protokół z Ogólnego Zebrania Towarzystwa Opieki nad Nieuleczalnie Chorymi z dnia 14 czerwca 1949 roku, s. 2.
} 
II Oddział Wewnętrzny Szpitala nr 6 przy ul. Goszczyńskiego (wcześniej Szpital Sióstr Elżbietanek). Chorych przewieziono do przytułku w Wyrozębach k. Sokołowa Podlaskiego, a wszystkie siostry otrzymały zwolnienie z pracy ${ }^{60}$.

W wyniku przemian politycznych po 1989 roku, cały teren zakładu, tj. dom dla chorych, dom sióstr z kaplicą oraz zabudowania gospodarcze i ogród przeszły na własność Zgromadzenia Sióstr Franciszkanek od Cierpiących. Oddział wewnętrzny został zlikwidowany. Urzędowa decyzja o przeniesieniu własności nosi datę 19 września 1990 roku. Po uzyskaniu praw własności zgromadzenie przystąpiło do budowy nowych obiektów na tym terenie. Dzięki staraniom sióstr, ale także dzięki wielu ofiarodawców, został wybudowany nowy budynek z przeznaczeniem na dom opieki dla ludzi starszych i niepełnosprawnych ${ }^{61}$. Od 1995 roku w Królikarni istnieje tzw. Dom św. Franciszka, którego oficjalna nazwa brzmi: Zakład Pielęgnacyjno-Opiekuńczy Dom św. Franciszka. Zakład świadczy opiekę wobec osób, które wymagają świadczeń pielęgnacyjno-opiekuńczych w zakresie całodobowym ze względu na stan zdrowia i stopień niepełnosprawności, brak samodzielności w samoopiece i samopielęgnacji, konieczność kontroli lekarskiej, potrzebę profesjonalnej pielęgnacji i rehabilitacji ${ }^{62}$.

\section{Bibliografia}

\section{Materiały źródłowe}

Archiwum Zgromadzenia Sióstr Franciszkanek od Cierpiących (dalej: AFC)

- sygn. B VI, T. I/Wiz, Wizytacje.

- sygn. B VI, T. I-Wiz/2, Księga wizyt Kanonicznych przeprowadzonych przez

Matkę Generalną Kazimierę Gruszczyńską, Magdalenę Lazowską oraz przez Delegatki Matek od 1917-1945.

${ }^{60}$ Zob. AFC, D I, T. I-Król/90, Zebrane wiadomości, s. 13.

${ }^{61}$ Zob. AFC, sygn. D I, T. III-Król/8, 100 lat służby cierpiącym oraz obecności Sióstr Franciszkanek od Cierpiących na terenie Królikarni, oprac. M. Ch or e m b a l s ka, s. 16.

${ }^{62}$ Zob. Regulamin Organizacyjny Zgromadzenia Sióstr Franciszkanek od Cierpiacych wzakresie wykonywania działalności leczniczej przez Zakład PielęgnacyjnoOpiekuńczy Dom św. Franciszka z dnia 30.12.2012 roku. 
- sygn. C I, T. II-MK - Materiały związane z życiem i działalnością Matki Kazimiery Gruszczyńskiej. Cz. 2.

- sygn. C I, T. II-MK/91, Życiorys śp. Kazimiery Gruszczyńskiej, Założycielki i długoletniej Prezeski „Towarzystwa Pielęgnowania Chorych Świętego Józefa - Przytulisko" w Warszawie.

- sygn. C I, T. II-MK/92, W. B u r si a k, Życiorys śp. Czcigodnej Matki Kazimiery Gruszczyńskiej Założycielki ukrytego Zgromadzenia Sióstr Franciszkanek od Cierpiących w Warszawie, t. II.

- sygn. D I, T. I-Król, Dokumentacja Zakładu dla Nieuleczalnie Chorych w Królikarni. Cz. 1.

- sygn. D I, T. I-Król/3, Protokół z posiedzenia Rady Opiekuńczej Towarzystwa Opieki nad Nieuleczalnie Chorymi z dnia 1 czerwca 1910 roku.

- sygn. D I, T. I-Król/3, Protokół z X posiedzenia Rady Opiekuńczej Towarzystwa Opieki nad Nieuleczalnie Chorymi z dnia 18 października 1898 roku.

- sygn. D I, T. I-Król/6, Księga osób wizytujących w przytułku dla nieuleczalnych w Królikarni (oraz sprawozdania z ruchu chorych - miesięczne i roczne zestawienia).

- sygn. D I, T. I-Król/22, Protokół z Ogólnego Zebrania Towarzystwa Opieki nad Nieuleczalnie Chorymi z dnia 24 października 1946 roku.

- sygn. D I, T. I-Król/22, Protokół z Ogólnego Zebrania Towarzystwa Opieki nad Nieuleczalnie Chorymi z dnia 14 czerwca 1949.

- sygn. D I, T. I-Król/36, Sprawozdanie z działalności Towarzystwa Opieki nad Nieuleczalnie Chorymi z 1921 roku.

- sygn. D I, T. I-Król/37, Informacja historyczna o Domu Zgromadzenia Sióstr Franciszkanek od Cierpiących - Królikarnia.

- sygn. D I, T. I-Król/38, Sprawozdanie z działalności Towarzystwa Opieki nad Nieuleczalnie Chorymi z 1926 roku.

- sygn. D I, T. I-Król/90, Prośba o wsparcie.

- sygn. D I, T. I-Król/90, Zebrane wiadomości historyczne o Królikarni.

- sygn. D I, T. II-Król, Dokumentacja Zakładu dla Nieuleczalnie Chorych w Królikarni. Cz. 2.

- sygn. D I, T. II-Król/11, Pismo do Władz Administracyjnych miasta Warszawy o rejestrację Towarzystwa Opieki nad Nieuleczalnie Chorymi z dnia 24 października 1946 roku.

- sygn. D I, T. II-Król/26, Sprawozdanie z działalności Towarzystwa Opieki nad Nieuleczalnie Chorymi z roku 1901.

- sygn. D I, T. II-Król/29, Sprawozdanie z działalności Towarzystwa Opieki nad Nieuleczalnie chorymi z roku 1903.

- sygn. D I, T. II-Król/30, Sprawozdanie z działalności Towarzystwa Opieki nad Nieuleczalnie Chorymi za rok 1915.

- sygn. D I, T. II-Król/31, Sprawozdanie z działalności Towarzystwa Opieki nad Nieuleczalnie Chorymi za rok 1917. 
- sygn. D I, T. II-Król/32, Sprawozdanie z działalności Towarzystwa Opieki nad Nieuleczalnie Chorymi za rok 1918.

- sygn. D I, T. II-Król/33, Pismo Prezesa Towarzystwa Opieki nad Nieuleczalnie Chorymi do Wydziału Opieki Społecznej i Zdrowia Publicznego Zarządu miejskiego w Warszawie z dnia 26 września 1934 roku w sprawie rewizji decyzji o obniżeniu dotychczasowej stawki dziennej na utrzymanie i leczenie chorych.

- sygn. D I, T. II-Król/34, Sprawozdanie z działalności Towarzystwa Opieki nad Nieuleczalnie Chorymi za rok 1919.

- sygn. D I, T. II-Król/35, Sprawozdanie z działalności Towarzystwa Opieki nad Nieuleczalnie Chorymi za rok 1920.

- sygn. D I, T. II-Król/47, Pismo Prezesa Towarzystwa Opieki nad Nieuleczalnie Chorymi do Ministerstwa Poczt i Telegrafów, Wydział Radiofoniczny z dnia 24 maja 1936 roku.

- sygn. D I, T. II-Król/49, Odezwa Zarządu Towarzystwa Opieki nad Nieuleczalnie chorymi.

- sygn. D I, T. II-Król/55, Sprawozdanie z działalności Towarzystwa Opieki nad Nieuleczalnie Chorymi za rok 1939.

- sygn. D I, T. II-Król/59, Sprawozdanie z działalności Towarzystwa Opieki nad Nieuleczalnie Chorymi za rok 1943.

- sygn. D I, T. III-Król/8, 100 lat służby cierpiącym oraz obecności Sióstr Franciszkanek od Cierpiących na terenie Królikarni, oprac. M. Chorembalska.

\section{Opracowania}

Bandrowski J., Najnieszczęśliwsi, Warszawa 1901.

Czermińska L., Wszystko zaczęło się w Kozienicach... Życie i dzieło Stugi Bożej Kazimiery Gruszczyńskiej, Kozienice 2017.

De Walden-Gałuszko K., Założenia i podstawy ruchu hospicyjnego, [w:] Pielęgniarstwo w opiece paliatywnej i hospicyjnej, (red.): K. de Walden-Gałuszko, A. Kaptacz, Warszawa 2005.

Historia medycyny, red. T. Brzeziński, Warszawa 1995.

Jodkowski H., Szpital w Królikarni, „Kronika Warszawy” 1975, nr 3/23, s. 37-49.

Olszewski D., W stużbie cierpiacym. Charyzmat Kazimiery Gruszczyńskiej (1848-1927), Niepokalanów 1991.

Podgórska-Klawe Z., Szpitale warszawskie w latach 1388-1945, Warszawa 1975. Ustawa Towarzystwa opieki nad nieuleczalnymi chorymi w mieście Warszawie, Warszawa 1898.

Świda T.T., Nieuleczalni w Królikarni. Garść wrażeń, „Tygodnik Ilustrowany" 1910, s. 32:651. 
JOLANTA KOWALIK CSFA

\author{
DZIALALNOŚĆ \\ TOWARZYSTWA OPIEKI NAD NIEULECZALNIE \\ CHORYMI W WARSZAWIE (1897-1949). \\ PRACA SIÓSTR FRANCISZKANEK OD CIERPIĄCYCH \\ W WARSZAWSKIEJ KRÓLIKARNI
}

Streszczenie: Jednym z naglących problemów służby zdrowia na terenie Warszawy w końcu XIX wieku była nierozwiązana kwestia osób cierpiących na nieuleczalne choroby. Brak odpowiednich placówek, gdzie można by ich było otoczyć stosowną opieką, powodował, że często umierali w nędzy i strasznych cierpieniach. Nadzieją dla tych „najnieszczęśliwszych” okazało się powołanie Towarzystwa Opieki dla Nieuleczalnie Chorych. Dzięki jego działalności stworzono zorganizowany system opieki dla tych chorych, który obejmował: 3 lecznice, w których udzielano doraźnej medycznej, a także materialnej pomocy chorym nieuleczalnie; utworzono zakład dla nieuleczalnych przy ul. Wspólnej, później przeniesiony do Królikarni, gdzie cierpiący na choroby nowotworowe objęci byli opieką szpitalną. W ramach działalności Towarzystwa udzielano pomocy chorym ,rakowatym” także w ich domach rodzinnych.

Od początku istnienia Towarzystwa Opieki nad Nieuleczalnie chorymi, w skład Rady Opiekuńczej weszła Założycielka Zgromadzenia Sióstr Franciszkanek od Cierpiących - Matka Kazimiera Gruszczyńska. Opiekę zaś nad chorymi powierzono jej duchowym córkom - siostrom franciszkankom od cierpiących. Swoją posługę wobec nieuleczalnie chorych objętych opieką Towarzystwa siostry sprawowały nieprzerwanie do lat 50. XX wieku, tzn. do czasu, kiedy zakład ostatecznie upaństwowiono i stworzono w nim oddział chorób wewnętrznych, jako filię szpitala przy ul. Goszczyńskiego. Wówczas chorzy nieuleczalnie zostali przewiezieni do szpitala w Wyrozębach, natomiast wszystkie siostry franciszkanki zwolniono z pracy. Po przemianach politycznych w 1989 roku, Zgromadzenie Sióstr Franciszkanek od Cierpiących odzyskało teren zakładu Królikarnia oraz nabyło prawo własności tej posesji. Staraniem sióstr oraz darczyńców na terenie Królikarni został wybudowany i w 1995 roku oddany do użytku i prowadzony przez zgromadzenie Dom św. Franciszka (tj. Zakład Pielęgnacyjno-Opiekuńczy Dom św. Franciszka), przeznaczony dla osób starszych i niepełnosprawnych.

Słowa klucze: nieuleczalni, Towarzystwo Opieki nad Nieuleczalnie Chorymi, Królikarnia, Kazimiera Gruszczyńska, Dom św. Franciszka, franciszkanki od cierpiących. 


\title{
THE ACTVITY OF THE SOCIETY FOR THE INCURABLY ILL IN WARSAW (1897-1949). THE WORK OF FRANCISCAN SISTERS OF IN "THE RABBIT HOUSE" (KRÓLIKARNIA) IN WARSAW
}

\begin{abstract}
One of the urgent problems of health care in Warsaw in the late $19^{\text {th }}$ century was the unresolved issue of people suffering from incurable diseases. The lack of appropriate facilities, where they could be taken care for, meant that they often died in poverty and terrible suffering. The appointment of the Society for the Incurably Ill was found to be a hope for those "unhappiest". Thanks to its activity, an organized system of care for these patients was created, which included: 3 hospitals, in which emergency medical assistance was provided, as well as material help for terminally sick patients; an institution for the incurably ill was established at Wspólna Street, later moved to "the Rabbit House" (Królikarnia), where people suffering from cancer were hospitalized. As part of the Society's activity, cancer patients were also helped in their family homes.

Since the beginning of the Society for the Incurably Ill, one of the members of the Council of Guardians was the Foundress of the Congregation of the Franciscan Sisters of Suffering - Mother Kazimiera Gruszczyńska. Care for the sick was entrusted to her spiritual daughters - the Franciscan Sisters of Suffering. The sisters continued their service to the terminally ill under the care of the Society until the 1950 's, i.e. until the institution was finally nationalized and turned into internal medicine ward, as a branch of the hospital at Goszczyńskiego Street. At that time, terminally ill patients were transported to the hospital in Wyrozęby, while all the Franciscan sisters were dismissed from work. After the political transformation in 1989, the Congregation of the Franciscan Sisters of Suffering regained the premises of "the Rabbit House" (Królikarnia) and acquired the ownership right to this property. Through the efforts of the sisters and donors the Nursing and Care House of St. Francis was built there for the elderly and the disabled, run by the Congregation.
\end{abstract}

Keywords: the terminally ill, Society for the Incurably Ill, "the Rabbit House" (Królikarnia), Kazimiera Gruszczyńska, House of St. Francis, Franciscan Sisters of Suffering. 
240 JOLANTA KOWALIK CSFA, LUCYNA CZERMIŃSKA CSFA 